\title{
The Valuation of Water Quality: A Conceptual Framework for Households' and Producers' Willingness to Pay in Dhaka, Bangladesh
}

\author{
Md. Ariful Islam ${ }^{*}$ Siti Aznor Ahmad ${ }^{2}$ Rabiul Islam ${ }^{3}$ \\ 1. School of Economics, Finance and Banking, Universiti Utara Malaysia, Sintok, Kedah, Malaysia. \\ 2. School of Economics, Finance and Banking, Universiti Utara Malaysia, Sintok, Kedah, Malaysia. \\ 3. School of International Studies, COLGIS, Universiti Utara Malaysia, Sintok, Kedah, Malaysia. \\ * E-mail of the corresponding author: arifbsbd@gmail.com
}

\begin{abstract}
Restoring the freshwater ecosystems has drawn global attention, governmental and non-governmental organizations around the globe incorporating several strategies to revive the last remaining free-flowing rivers and other high priority freshwater ecosystems. Rivers in urban setting have social, economic and ecological importance and demise of such rivers might affect many of its inhabitant's life and living which has been established, survived and flourished over the years. Often, restoration of the river ecosystem seems challenging to the policy makers because the river ecosystem services have no price tag. Improving water quality program requires precise information about the costs and benefits which in urban areas needs to incorporate an integrated approach that implement necessary societal and technical measures. This study provides a conceptual framework using both households' and producers' willingness to pay for the river water quality improvement to acquire maximum information for successful restoration program. This study provides useful information which may help for further improvement of the water quality in an alike problem of developing countries. Future studies should validate empirically the proposed research framework.
\end{abstract}

Keywords: Urban River Restoration, Households’ WTP, Producers’ WTP, Conceptual Framework

DOI: $10.7176 / \mathrm{JESD} / 10-2-18$

\section{Introduction}

The water quality crisis confronts the present world due to results of the increased growth of pollution in water bodies such as rivers, lakes, and wetlands. The water is polluting because of continuous growth in population, urbanisation, industrialisation, change of land use and food production practices, poor water use practice and overall strategic inefficiency in wastewater management. The ultimate impact of water pollution on water resources disrupting the humans' life support system (United Nations [UN], 2015). The United Nations Educational, Scientific and Cultural Organization [UNESCO], 2016) reveals that 80 percent of sewage waste in developing countries have been discharged into rivers or seas without proper treatment, while about 1.8 billion people use fecally contaminated water as a source of drinking water globally. Accordingly, about 1,000 children die each day due to preventable water and sanitation related diarrhoeal diseases.

Water availability is highly dependent on water quality while the poor-quality water may not be used for different purposes. A recent study by the International Food Policy Research Institute (IFPRI) and Veolia states that: 'Water quality deterioration is projected to rapidly increase over the next several decades which, in turn, will increase risks to human health, economic development and ecosystems' (IFPRI \& Veolia, 2015, p. 3). Human life and ecological diversity greatly depend on freshwater sources such as wetlands, lakes, and rivers provided that having a standard water quality. The water quality of many rivers in several developing countries has been found worst and contaminated with chemical pollutants and pathogens from untreated urban runoff and sewage. This is because primarily of higher population and economic growth within these countries (United Nations Environment Program [UNEP], 2015).

The challenge to overcome water pollution problem or restoring water quality at standard level is important but more multifaceted in developing countries than developed ones (UNEP, 2015; UN, n.d.). For example, at present, the serious water pollution is witnessing by the rivers of emerging economies such as China, India, and Brazil. The major rivers in China face unprecedented pollution because of large scale industrial and urban development and agricultural runoff. For instance, a study financed by the World Wildlife Fund (WWF) documents that the 
river Yangtze, one of the largest rivers in China, receives about 25 billion tons of sewage and industrial waste annually. The sewage and effluents of industries account for 42 percent and 45 percent respectively of country's total wastewater discharge into Yangtze River. The health impacts are substantial throughout the Yangtze River basin; intestinal infectious diseases such as hepatitis A and dysentery found nearby cities of the Yangtze, which is higher than the national average. Moreover, E. coli bacteria found as high as 15000 per liter in some part of the cities which is alarming for the human health (Wong, Williams, Collier, Schelle, \& Pittock, 2007).

The majority of the rivers of India are also experiencing acute water pollution problems. For example, the Yamuna, a mighty river of India, faces severe stress on its water flow because of excessive industrialisation and urbanisation. Water quality has critically impaired over the years, thereby human health and ecosystem at great risk. The Central Pollution Control Board's (CPCB) report reveals that 121 of 275 Indian rivers become severely polluted with a primary cause of sewage waste (CPCB, 2015, p. 27). Still-growing population with unplanned urbanisation and industrial activities identified as the main causes of water quality deterioration of these rivers. A study of Do, Joshi, and Stolper (2016) summarises that there is a strong and long-lasting association between river pollution and infant mortality in India, whereby Alsan and Goldin (2015) emphasise on effective water and sewerage infrastructures in managing watersheds to control infant mortality. The water quality crisis will hamper India's sustainable development goals unless some effective measures are not taken to improve the water quality of these rivers (Burke, 2015).

Many of Brazil's rivers are also highly contaminated with untreated sewage and industrial waste. Unfortunately, the Brazilian government has not much responsible in caring for its river resources in the last few decades. The population boom and the rapidly growing cities with inadequate urban design have resulted in the rivers as the dumping station of untreated industrial waste and sewage (Silva et al., 2016). As a result, many of the important water resources in Brazil have died, the major rivers of Brazil such as Rio Tietê, Rio Iguaçu, Rio Ipojuca, Rio dos Sinos and Rio Gravataí have seriously polluted (Pomela, 2015). The polluted water is bubbling with bacteria and low in oxygen which is a good breeding ground for mosquitoes and other harmful insects. A mosquito causes many of the waterborne diseases such as Malaria, Filarial, and Dengue. Public-health experts say sewage beat mosquito is the main vectors for the Zika virus which would lead outbreak in some Brazilian's cities if sewage is not properly managed (Khazan, 2014; Triunfol, 2016).

The rivers in other developing countries such as Bangladesh are also struggling to overcome the crisis of water quality, particularly in the urban regions. Many urban rivers such as Surma in Sylhet, Karnafuli in Chittagong and Balu, Turag, Dhaleswari, Shitalakhya and Buriganga in Dhaka become seriously polluted. The environment and human life of Bangladesh will be badly affected if the rivers managed poorly. This paper aims to provide a conceptual framework using both households' and producers' willingness to pay for the river water quality improvement to acquire maximum information for successful restoration program. The framework will be best suited with stated preference methods of contingent valuation or contingent choice method to evaluate total willingness to pay.

\section{Literature Review}

Bangladesh is characterized by high population growth, urbanization, and industrialization. Being the sociopolitical and industrial centre of the country, Dhaka is severely affected by the problem of water pollution that tributaries and the major rivers are highly polluted by receiving sewage effluents and solid and liquid wastes from industries. The UN-HABITAT reports that the city has been experiencing severe urban water pollution, inadequate clean water, and poor sanitation problem for its residents (UN-HABITAT, 2016). According to The Economist Intelligence Unit's Global Livability Ranking, Dhaka placed the 3rd worst city in the world to live, while Damascus placed 1st on the worst city ranking. However, severe water pollution is one of the key causes of the backwardness of Dhaka city (The Economic Intelligence Unit [EIU], 2012).

Megacity Dhaka with a population of more than 17 million is a typically unplanned and urbanized city in the world (BBS, 2015). Moreover, about 400,000 new residents annually migrating from rural areas seeking a better life in Dhaka is straining under the pressure of its rapidly swelling population (UN-HABITAT, 2016, p. 34). If population estimates hold true, Dhaka is expected to grow to 20 million by 2020, making it the world's third largest city (BSS, 2015). Therefore, the giant population exerts enormous pressure on the environment and both water quality and quantity (Bangladesh Economic Review, 2015). High population growth also helps increase the municipal solid and liquid waste generation manifolds in Dhaka. Moreover, insufficient municipal waste collection and poor sewerage system help increase the problem of pollution. Waste Concern reports that only $15 \%$ of total generated waste in Dhaka are recycled and the rest are dumped in open sites, drainage channels, 
rivers and streets (WASTE CONCERN, 2009); as a result, it greatly contributes to the pollution of rivers since all wastes dumped in other places eventually end up in rivers during runoffs (Chowdhury, Rashid, \& Hoque, 2014).

Since the city has the inadequate and inefficient management of waste and sewerage systems, it has encouraged to raise all sort of effluents to be discharged into adjacent waterways from both the point and non-point sources in the city. According to the annual report of WASA, the sewerage connection has only 30 percent coverage in the city which collects municipal sewage wastewater for treatment, while the major portion of untreated wastewater fall straight to rivers (DWASA, 2015). For instance, statistics shows that the residents of Dhaka generate around 360,000 cube meter of excreta daily. More than 80 percent or 288,000 cube meters of the untreated sewage wastewater are directly discharged into the nearby rivers (DWASA, 2015), which exaggerate the water pollution of urban rivers and pose human health hazards.

At present over 8000 small and medium industries have been operating in and around Dhaka city, while half of the total industries in greater Dhaka have no individual's effluent treatment plant (ETP), those who have this facility are not using properly (DoE, 2011). As a result, almost all the untreated industrial effluents discharge directly into the adjoining rivers. A newspaper recently reports that around 1,40,000-1,45,000 cubic meters untreated industrial waste is being released every day into four surrounding rivers of Dhaka, while Buriganga alone receives 80,000 cubic meters of total effluents daily (UNB, 2016). On the other hand, infiltration of industrial effluents to groundwater has severe adverse impacts on quality of potable water supplies and potentially poses a serious risk to public health. The industrial effluents contain both the human pathogens and chemical hazards which have a negative impact on human, animal and aquatic health (Ahmed, Shaheen, et al., 2015).

According to the department of environment (DoE), water quality of the peripheral rivers in Dhaka city has failed to comply the environmental quality standard (EQS) and the rivers are grossly polluted throughout their courses except in monsoon (DoE, 2013). The four urban rivers have declared as the ecologically critical areas (ECA) in 2009 by the DoE because of severe pollution. All these rivers suffer severely due to receiving huge sewage and industrial effluents. The recent report published by the department of environment (DoE) shows that the level of dissolved oxygen (DO) in several points of River Buriganga is "zero" (DoE, 2013). The same trend has been recording over the years by river monitoring department. Not only the dissolved oxygen (DO) but other important water quality parameters such as biological oxygen demand (BOD), chemical oxygen demand (COD) and $\mathrm{pH}$ level also failed to comply with the environmental quality standard set by the DoE. Hence the river water shouldn't be used for irrigation, drinking, livestock drinking and washing (Chowdhury, Rashid, \& Hoque, 2014; Hossain, Ahmed, Abdullah, Akbor, \& Ahsan, 2015).

The World Bank documented that more than $80 \%$ of the Dhaka Statistical Metropolitan Area (DSMA) is still used for agriculture and fisheries. However, these activities have declined sharply as water pollution has increased. In polluted areas, some $45 \%$ of households report persistent losses in the production of rice, and more than $20 \%$ are experiencing production losses in vegetable crops. Reflecting experience with the death of livestock after drinking river water, less than $15 \%$ of households in highly polluted areas allow livestock to drink river water, compared with more than half in the past. It is estimated that agricultural and fisheries production in the DSMA may be reduced by about one-third as a result of poor water quality (World Bank, 2008).

Despite knowing the above fact, these urban rivers have been being extensively utilized by many recipients of urban Dhaka for various purpose such as irrigation, washing vegetables and clothes, bathing, drinking and recreational purpose (Alam, 2013). The negative impacts of using wastewater have been identified by several studies. For example, studies of Hossain et al. (2015), Ahmed, Baki, et al. (2015) and Ahmed, Shaheen, et al. (2015) found the presence of toxic substances in several fish populations of river Buriganga and Turag. On the other hand, by using the wastewater, farmers grow several cash crops like red amaranth, radish, cabbage, carrot, gourd, pumpkin gourd, and other leafy vegetables in the urban and peri-urban area, and it is found the harmful toxins substances in such vegetables (Islam, Ahmed, Habibullah-A1-Mamun, \& Masunaga, 2014; Mohiuddin, Alam, Rahman, Islam, \& Ahmed, 2016; Sarkar et al., 2015; Uddin, Khanom, Al Mamun, \& Parveen, 2016). Experts warned that the using of wastewater in crop production can deteriorate the public health situation in Dhaka city (Chaudhary, Mishra, \& Kumar, 2016; Hossain et al., 2015; Lu et al., 2015).

High dependence on groundwater has led to decreasing the replenishing capacity of groundwater aquifer of Dhaka city. The study shows that Dhaka WASA has 772 deep tube wells which abstracting about 2800-millionliter water per day causing a serious reduction in the groundwater table; estimated dropping of groundwater aquifer level is 3 meters annually (DWASA, 2015). As the groundwater abstraction is no more environmentally 
sustainable, meeting ever increasing water demand for the growing population appears as the greatest problem for Bangladesh. At present, one-fourth of the water supply for Dhaka city comes from two rivers such as Buriganga and Shitalaykha. However, the government has already taken a plan to shift the water supply paradigm from groundwater by emphasizing surface water as the major source of water supply in Dhaka city (DWASA, 2015). But serious water pollution problem makes it difficult to process river water into useable quality.

People appreciate and enjoy places beside the water. This is recognized as the time-proven experience in Dhaka city. For example, Dhanmondi Lake and Hatirjheel Lake in Dhaka City provide waterside recreational facilities for the congestion city life. However, recreational open space in Dhaka City is significantly low compared to the national standard set by the Detailed Area Plan (DAP), Ministry of Housing and Public Works. The DAP recommends recreational open space is 0.96 acre of land for 1000 population, while in Dhaka City, only 0.07 acre of land is shared by 1000 population for their recreational activities which are far off from the standard level. Though Dhaka city has circular waterways system, extremely bad odors from polluted water restrain the city residents from recreational opportunities, thereby impacting healthy living. Recently, the Rajdhani Unnayan Kortipokhho (RAJUK) or Capital Development Authority has made Dhaka Structure Plan 2016-2035 and set objectives to build a sustainable city for the city dwellers. One of the important objectives of RAJUK is "to conserve water bodies as a source of local aesthetics and recreation by designing urban waterbodies with landscape and green belt, sitting arrangement, walkways on both sides of conservable waterbodies". Therefore, it is required a proper river management while improving water quality is the prerequisite which plays a pivotal role in waterside recreation (Keeler et al., 2015; Lopes, Davies-Colley, Von Sperling, \& Magalhães, 2016). However, to implement such environmental improvement project, it is anticipated that plenty of information has available to the hand of policymakers so as to gauge benefits and costs of that project. Unfortunately, the studies of environmental valuation, particularly on the water quality, have substantially overlooked in Bangladesh.

Recently the attention within Bangladesh has been growing on improving water quality in urban rivers aiming to have maximum benefits for the urban residents (Alam, 2013; Islam, 2015: and Islam, Ahmad and Islam, 2018). However, the common argument is that urban rivers in Dhaka are contaminated because of the poor sewerage system, uses of old technology, lack of awareness on waste management, weak enforcement mechanisms on pollution prevention and regulation and lack of cooperation among stakeholders (Alam, 2013; Hoque \& Clarke, 2013; Islam, 2015). Therefore, a lack of integration of environmental issues in future water improvement activities may lead to social and environmental pollution problems which in return create a problem on drinking water scarcity and public health hazards and may require enormous resources when the need is there to improve the water quality (Chaudhary et al., 2016).

Undoubtedly, the worst water quality of urban rivers certainly affects the urban life through reducing the availability of freshwater and increasing public health threat to the Dhaka megacity. However, the notion of improving water quality for this study is to meet water demand for households, industries, and recreational purpose. The early studies on river water quality improvement for a recreational use found to have many in developed countries. But in developing countries, it is very scarce. On the other hand, a study found in Bangladesh which measures the attitudes and perceptions regarding river restoration, overlooking the value of water quality improvement. However, as the groundwater resource depleting extensively, the water supply to the households and industries in coming years appears as a great challenge for DWASA to meet the future water demand, thereby need to know how the households and industries place value on surface water and its quality. While both the households and industries are responsible for water pollution, many studies have measured the willingness to pay for improving water quality from the households' perspective only. Though a few studies have measured the producers' willingness to pay in other areas such as information uncertainty (Roe \& Antonovitz, 1985), crop insurance (Patrlck, 1988), agriculture extension services (Budak \& Budak, 2010), the author's best knowledge, studies considering producers' willingness to pay for improving water quality is seriously overlooked. This study will fill this research gap by measuring willingness to pay for improving the water quality of both the households' and producers' through installing centralized wastewater treatment plant in Dhaka City. 


\section{Conceptual Framework of the Study}

The conceptual framework developed for this study is presented below which shows how the valuation of water quality will be conducted (see Fig 1).

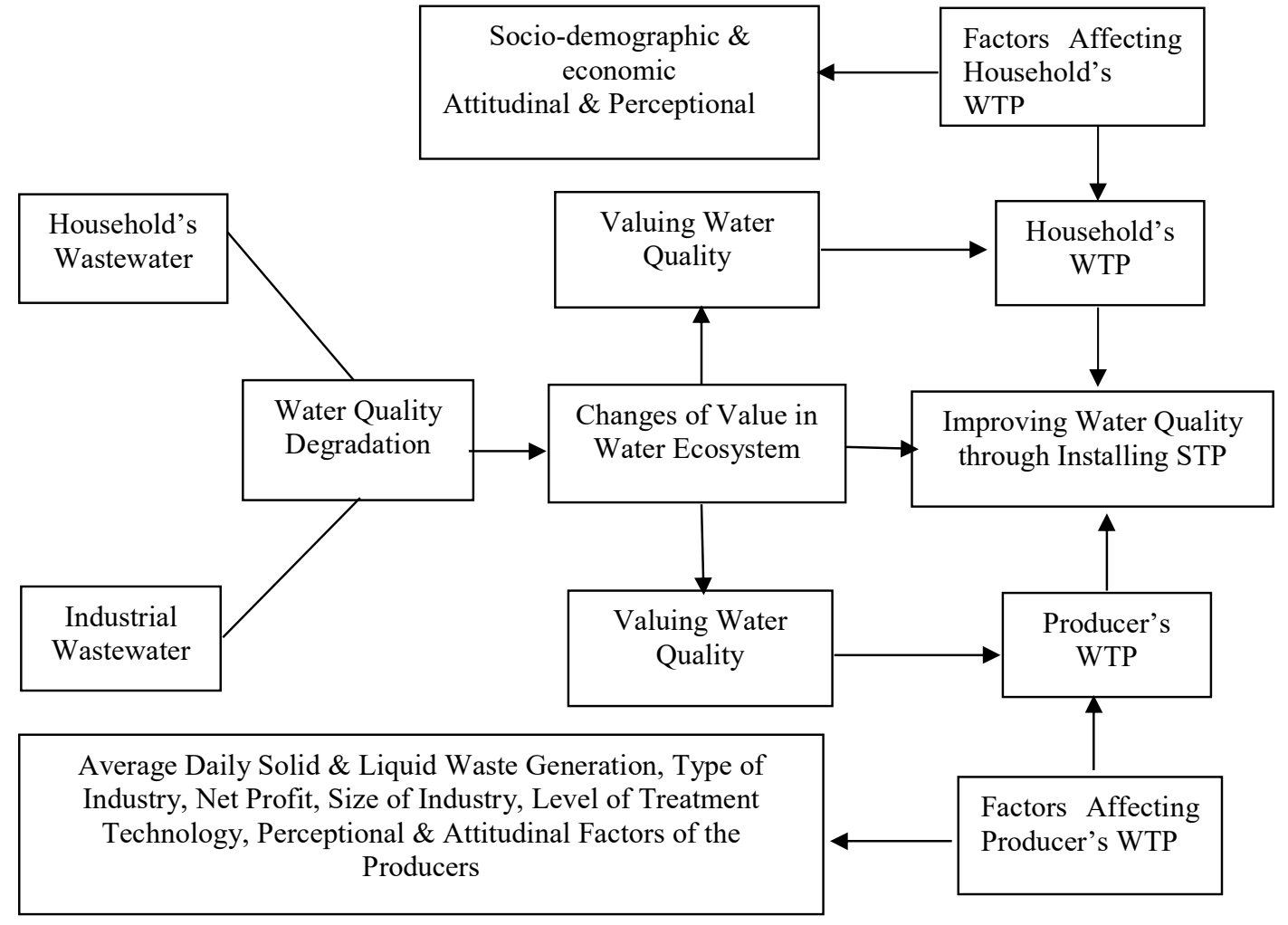

Fig 1: Framework for Measuring Value

\section{Conclusion}

As the river water quality is very important for the wider communities' ranges from humankind to aquatic species, this study will explore the benefit estimation of improving water quality of river Buriganga in Bangladesh, government investment on environmental improvements projects as well as the research in this field is still growing (Alam, 2013; Mohammed, 2009). Since rivers provide us with general life support, water supply, transportation, waste assimilation, and a wide array of recreation and tourism activities, preservation and protection of rivers' water quantity and quality is very important. Unfortunately, the quality and quantity of water in urban peripheral rivers of Bangladesh have not been maintained with priority, it may be due not knowing the actual value of quality water.

Although, numerous studies have been conducted on these rivers to investigate water quality and its environmental consequences, study to estimate economic benefit of improving water quality is neglected. This study will be addressed to overcome this issue. While existing studies on valuing the costs-benefits of river restoration in urban rivers in Dhaka have various limitations because of methodological issues and data problems, the present study differs from the previous studies in several respects. This study clearly defines the hypothetical market which will capture the perceptions of the residents to avoid estimation bias. On the other hand, this study is the first its kind to measure producers' WTP for improving surface water quality which will be expected to contribute to the policy debates on the investments in water pollution clean-up activities in developing countries and Bangladesh in particular. More importantly, policy-makers will have a better understanding for the installing of the centralize wastewater treatment plant to control water pollution of urban rivers in Dhaka. The valuation of environmental goods and services is a complex and multi-dimensional task to be completed particularly in developing countries where information is limited, and people are less concern. However, this study will be identified the factors that influence both the households' and producers' willingness to pay toward improving the water quality of rivers in Dhaka. Overall, the results will convey important information from the stakeholders to the authorities with regard to pertinent improvements plan or action for restoring the water quality of polluted 
rivers in other developing countries. The scope for further studies can be designed empirically with both the households' and producers' willingness to pay to validate this proposed conceptual framework in other field of environmental valuation.

\section{References}

Ahmed, M. K., Baki, M. A., Islam, M. S., Kundu, G. K., Habibullah-Al-Mamun, M., Sarkar, S. K., \& Hossain, M. M. (2015). Human health risk assessment of heavy metals in tropical fish and shellfish collected from the river Buriganga, Bangladesh. Environmental Science and Pollution Research, 22(20), 15880-15890.

Ahmed, M. K., Shaheen, N., Islam, M. S., Habibullah-al-Mamun, M., Islam, S., Mohiduzzaman, M., \& Bhattacharjee, L. (2015). Dietary intake of trace elements from highly consumed cultured fish (Labeo rohita, Pangasius pangasius and Oreochromis mossambicus) and human health risk implications in Bangladesh. Chemosphere, 128, 284-292.

Alam, K. (2013). Factors Affecting Public Participation in River Ecosystem Restoration: Using the Contingent Valuation Method. The Journal of Developing Areas, 47(1), 223-240.

Alsan, M., \& Goldin, C. (2015). Watersheds in Infant Mortality: The Role of Effective Water and Sewerage Infrastructure, 1880 to 1915. National Bureau of Economic Research.

Bangladesh Bureau of Statistics. (2015). POPULATION PROJECTION OF BANGLADESH: DYNAMICS AND TRENDS 2011-2061. Dhaka.

Budak, D. B., \& Budak, F. (2010). Livestock producers needs and willingness to pay for extension services in Adana province of Turkey. African Journal of Agricultural Research, 5(11), 1187-1190.

Burke, J. (2015, April 7). Half of India's rivers are polluted, says government report. Retrieved from https://www.theguardian.com/world/2015/apr/07/half-india-rivers-polluted-new-government-report

Chaudhary, M., Mishra, S., \& Kumar, A. (2016). Estimation of water pollution and probability of health risk due to imbalanced nutrients in River Ganga, India. International Journal of River Basin Management, 1-8.

Chowdhury, F., Khan, I. A., Patel, S., Siddiq, A. U., Saha, N. C., Khan, A. I., ... Qadri, F. (2015). Diarrheal illness and healthcare seeking behavior among a population at high risk for diarrhea in Dhaka, Bangladesh. PLoS ONE, 10(6).

Chowdhury, R. A., Rashid, T., \& Hoque, S. (2014). Assessing Surface Water Quality Using Landsat TM and In Situ Data: An Exploratory Analysis. In Dhaka Megacity (pp. 301-318). Springer.

CPCB. (2015). The Central Pollution Control Board annual report 2014-15. New Delhi. Retrieved from http://cpcb.nic.in/upload/AnnualReports/AnnualReport_55_Annual_Report_2014-15.pdf

Department of Environment. (2011). Survey and Mapping of Environmental Pollution from Industries in Greater Dhaka (SMEP-GD). Dhaka.

Department of Environment. (2013). Surface Water Quality Report- 2013. Dhaka.

Dhaka Water and Sewerage Authority. (2015). Annual Report. Dhaka. Retrieved from http://dwasa.org.bd/wpcontent/uploads/2016/08/Annual-Report0001.pdf

Do, Q.-T., Joshi, S., \& Stolper, S. (2016). Can environmental policy reduce infant mortality? evidence from the Ganga pollution cases.

Hitzhusen, F. J. (2007). Economic Valuation of River Systems. Edward Elgar Publishing.

Hoque, A., \& Clarke, A. (2013). Greening of industries in Bangladesh: pollution prevention practices. Journal of Cleaner Production, 51, 47-56.

Hossain, M. S., Ahmed, F., Abdullah, A. T. M., Akbor, M. A., \& Ahsan, M. A. (2015). Public Health Risk Assessment of Heavy Metal Uptake by Vegetables Grown at a Waste-water-Irrigated Site in Dhaka, Bangladesh. Journal of Health and Pollution, 5(9), 78-85.

IFPRI and Veolia. (2015). The murky future of global water quality. Retrieved from http://www.veolianorthamerica.com/sites/g/files/dvc596/f/assets/documents/2015/04/IFPRI_Veolia_H2OQual_WP. pdf

Islam, M.A., Ahmad, S.A., \& Islam, R. (2018). Estimating Willingness to Pay for Improving River Water Quality Using Contingent Valuation Method: A Conceptual Framework. International Journal of Management, Accounting and Economics, 5(8), 643

Islam, M. S., Ahmed, M. K., Habibullah-Al-Mamun, M., \& Masunaga, S. (2014). Trace metals in soil and vegetables and associated health risk assessment. Environmental Monitoring and Assessment, 186(12), 8727-8739.

Islam, N. (2015). Urbanization in Bangladesh: Challenges and opportunities. In Conference Towards Sustained Eradication of Extreme Poverty in Bangladesh, Dhaka.

Keeler, B. L., Wood, S. A., Polasky, S., Kling, C., Filstrup, C. T., \& Downing, J. A. (2015). Recreational demand for clean water: evidence from geotagged photographs by visitors to lakes. Frontiers in Ecology and the Environment, 13(2), $76-81$. 
Khazan, O. (2014, April 18). The Site of Several 2016 Olympic Aquatic Events Has 195 Times the Safe Amount of Sewage in the Water. Retrieved from http://www.theatlantic.com/health/archive/2014/04/rio-is-literally-swimming-inpoop/360860/

Lopes, F. W. A., Davies-Colley, R. J., Von Sperling, E., \& Magalhães, A. P. (2016). A water quality index for recreation in Brazilian freshwaters. Journal of Water and Health, 14(2), 243-254.

Lu, Y., Song, S., Wang, R., Liu, Z., Meng, J., Sweetman, A. J., ... Wang, T. (2015). Impacts of soil and water pollution on food safety and health risks in China. Environment International, 77, 5-15.

Mohammed, E. (2009). Measuring the Benefits of River Quality Improvement Using the Contingent Valuation Method: The Case of the Ping River, Chiang Mai, Thailand. Journal of Environmental Assessment Policy \& Management, 11(3), 349-367.

Mohiuddin, K. M., Alam, M. M., Rahman, M. S., Islam, M. S., \& Ahmed, I. (2016). Effect of polluted river water on growth, yield and heavy metal accumulation of red amaranth. Research in Agriculture Livestock and Fisheries, 3(1), 53-65.

Patrlck, G. F. (1988). MALLEE WHEAT FARMERS'DEMAND FOR CROP AND RAINFALL INSURANCE. Australian Journal of Agricultural Economics, 32(1), 37-49.

Pomela, M. (2015). 10 Most Polluted Rivers in Brazil. Retrieved October 15, 2016, from http://thebrazilbusiness.com/article/10-most-polluted-rivers-in-brazil

Roe, T., \& Antonovitz, F. (1985). A producer's willingness to pay for information under-price uncertainty: Theory and application. Southern Economic Journal, 382-391.

Sarkar, M., Rahman, A. K. M. L., Islam, J. B., Ahmed, K. S., Uddin, M. N., \& Bhoumik, N. C. (2015). Study of hydrochemistry and pollution status of the Buriganga river, Bangladesh. Bangladesh J. Sci. Ind. Res., 50(2), 123134.

The Economic Intelligence Unit. (2012). Best cities ranking and report. London. Retrieved from http://pages.eiu.com/rs/eiu2/images/EIU_BestCities.pdf

The United Nations Educational Scientific and Cultural Organization. (2016). Water and Jobs. Paris. Retrieved from http://unesdoc.unesco.org/images/0024/002439/243938e.pdf

The United Nations Environmental Programme. (2001). Bangladesh: State of the Environment. Retrieved from http://www.rrcap.ait.asia/Publications/bangladesh soe.pdf

The World Bank. (2008). Policies for Mainstreaming Strategic Environmental Assessment in the Urban Development of Greater Dhaka (No. 68831

Triunfol, M. (2016). A new mosquito-borne threat to pregnant women in Brazil. The Lancet Infectious Diseases, 16(2), 156157.

Uddin, M. J., Khanom, S., Al Mamun, S., \& Parveen, Z. (2016). Effects of irrigation water on some vegetables around industrial areas of Dhaka. Bangladesh Journal of Scientific Research, 28(2), 151-159.

UN-HABITAT. (2016). Urbanization and Development: Emerging Futures. Nairobi. Retrieved from http://nua.unhabitat.org/uploads/WCRFullReport2016_EN.pdf

UNB. (2016, July 13). All waste-flowing points must be plugged to save Buriganga: Experts. The Independent. Retrieved from http://www.theindependentbd.com/home/printnews/51052

UNEP. (2015). The United Nations Environment Program Annual Report 2015. Retrieved from https://wedocs.unep.org/rest/bitstreams/11114/retrieve

United Nations. (2015). CL E A N WAT ER AND SANITATION: WHY IT MATTERS.

United Nations (UN). (n.d.). International Decade for Action "WATER FOR LIFE" 2005-2015. Retrieved October 23, 2016 , from http://www.un.org/waterforlifedecade/quality.shtml

Vaz S. Silva, S., Dias, A. H. C., Dutra, E. S., Pavanin, A. L., Morelli, S., \& Pereira, B. B. (2016). The impact of water pollution on fish species in southeast region of Goiás, Brazil. Journal of Toxicology and Environmental Health, Part A, 79(1), 8-16.

WASTE CONCERN. (2009). Waste Data Base of Bangladesh. Dhaka.

Wong, C. M., Williams, C. E., Collier, U., Schelle, P., \& Pittock, J. (2007). World's top 10 rivers at risk. Esocialsciences. Com Working Papers.

World Water Assessment Programme. (2015). The United Nations World Water Development Report 2015: Water for a Sustainable World. 